\title{
Analisis Faktor-Faktor Eksternal Yang Mempengaruhi Produktivitas Tenaga Kerja Pada Pekerjaan Pembuatan Batako
}

\author{
Sebastianus Baki HENONG ${ }^{1 *} \cdot$ Reginaldo Ch. LAKE ${ }^{2}$ \\ ${ }^{1}$ Program Studi Teknik Sipil, Fakultas Teknik, Universitas Katolik Widya Mandira Kupang, email : \\ sebasthenong00@gmail.com \\ ${ }^{2}$ Program Studi Arsitektur, Fakultas Teknik, Universitas Katolik Widya Mandira Kupang, email : \\ egilake@yahoo.com
}

\begin{abstract}
Labor productivity is the ratio between output and input, or the comparison between product results and the total resources used. Based on several field observations, the productivity of labor spread across the city of Kupang, especially in brick production, varies greatly. As a result of varying productivity, the results obtained are also very varied. This research was completed with a multiple regression analysis method that began with the collection of raw data through site surveys the distribution of questionnaires to respondents including the owners of brick companies and brick workers in the city of Kupang. Of the five external factors that are used to determine how they affect the productivity of brickworkers in Kupang City, the influence factor is the weather. The significant value of the effect of $X 3$ on $Y$ was $0.279>0.05$ and the $t$ value was $2.095>t$ table 2.00758. Thus it can be concluded that $H 3$ is accepted which means there is an influence of X3 on Y. While the other four factors namely the distance of raw materials to the production machine, cleanliness, wages and motivation do not affect the productivity of the brickworkers.
\end{abstract}

Keywords: project, brick, productivity, labor, kupang city

\section{Pendahuluan}

Pembangunan proyek konstruksi di Kota Kupang sepuluh tahun terakhir ini mengalami perkembangan yang sangat pesat. Banyak gedung-gedung bertingkat seperti hotel, sekolahsekolah, kampus, kantor swasta maupun pemerintah, rumah toko (ruko) serta pusat-pusat hiburan lainnya dibangun guna mengakomodir kebutuhan masyarakat. Masyarakat akan sejahtera, perekonomian akan maju dan juga kehidupan sosial semakin dinamis jika didukung oleh infrastruktur yang baik.

Dalam membangun sebuah proyek konstruksi selalu membutuhkan berbagai macam sumber daya yang menunjang terselesainya pekerjaan proyek tersebut. Salah satu sumber daya yang sangat penting ialah tenaga kerja. Tenaga kerja merupakan salah satu unsur penting dalam pelaksanaan suatu proyek karena pengaruhnya yang cukup besar terhadap biaya dan waktu penyelesaian. Namun perlu diperhatikan juga bahwa tenaga kerja merupakan sumber daya yang komplek dan sulit diprediksi sehingga diperlukan adanya usaha dan pemikiran lebih mendalam dalam pengelolaan tenaga kerja.

Produktivitas tenaga kerja adalah perbandingan antara output dan input, atau perbandingan antara hasil produk dengan total sumber daya yang digunakan. Jika Produktivitas naik ini hanya dimungkinkan oleh adanya peningkatan efisiensi yang terdiri waktu, bahan, tenaga

*penulis korespondensi 
dan sistem kerja, teknik produksi dan adanya peningkatan keterampilan dari tenaga kerjanya. Dengan demikian dapat dikatakan bahwa seorang tenaga kerja dikatakan produktif apabila mampu menghasilkan barang atau jasa sesuai dengan diharapkan dalam waktu yang singkat atau tepat.

Berdasarkan beberapa pengamatan lapangan, produktivitas tenaga kerja yang tersebar di Kota Kupang khususnya dalam pekerjaan pembuatan batako, sangat bervariasi. Akibat prodiktivitas yang bervariasi, hasil yang diperoleh pun sangat bervariasi. Ada beberapa batako yang ketika ditimbang sangat berat namun ketika dipegang butiran-butiran campuran terkelupas dan tercerai berai. Ada juga jenis batako yang cukup ringan namun sangat kuat. Perbedaan ini dikarenakan oleh campuran beton yang bervariasi. Selain itu juga umur pekerja, pengalaman pekerja pendidikan pekerja dan lingkungan, manajerial, motivasi serta peralatan yang digunakan juga sangat mempengaruhi.

Berdasarkan uraian ini maka perlu dianalisis secara lebih mendalam dan terperinci untuk semua perusahaan yang ada di Kota Kupang Faktor-faktor Eksternal yang mempengaruhi produktivitas tenaga kerja pada pekerjaan pembuatan Batako. Tujuan dari penelitian ini yakni mengetahui hubungan antara faktor Eksternal (Lingkungan kerja, Cuaca, Upah, Motivasi) dengan produktifitas tenaga kerja pada pekerjaan pembuatan Batako di Kota Kupang, Nusa Tenggara Timur.

\section{Tinjauan Pustaka}

\section{Pengertian Produktivitas}

Ervianto (2004), dalam bukunya Teori-Aplikasi Manajemen Proyek Konstruksi mengatakan bahwa produktivitas didefenisikan sebagai rasio antara output dan input, atau rasio antara hasil produk dengan total sumber daya yang digunakan. Menurut Hasibuan (1996) Produktivitas adalah perbandingan antara output (hasil) dengan input (masukan). Jika Produktivitas naik ini hanya dimungkinkan oleh adanya peningkatan efisiensi (waktu-bahantenaga) dan sisitem kerja, teknik produksi dan adanya peningkatan keterampilan dari tenaga kerjanya.

\section{Faktor-Faktor Yang Mempengaruhi Produktivitas}

Menurut Soeharto (2001), variabel-variabel yang mempengaruihi produktivitas tenaga kerja lapangan dapat dikelompokkan menjadi: 1. Kondisi fisik lapangan dan sarana bantu. 2. Supervisi, perencanaan dan koordinasi 3. Komposisi kelompok kerja 4. Kerja lembur 5. Ukuran besar proyek 6. Kurva pengalaman (learning curve) 7. Pekerja langsung versus subkontraktor 8. Kepadatan tenaga kerja

\section{Pengukuran Produktivitas}

Di dalam setiap proyek konstruksi selalu melalui rangkaian aktivitas pekerjaan yang belum tentu sama untuk menghasilkan satu produk fisik sejenis. Banyak hal yang mempengaruhinya, tergantung input seperti tenaga kerja, alat, material, dana dan rancangan, sedangkan untuk menghasilkan output juga tergantung pada proses konstruksinya yang kompleks. Untuk mengukur suatu produktivitas perusahaan dapatlah digunakan dua jenis ukuran jam kerja manusia, yakni jam-jam kerja yang harus dibayar dan jam- jam kerja yang dipergunakan untuk bekerja. Jam kerja yang harus dibayar meliputi semua jam-jam kerja yang harus dibayar, ditambah jam-jam yang tidak digunakan untuk bekerja namun harus dibayar, liburan, cuti, libur karena sakit, tugas luar dan sisa lainnya. Jadi bagi keperluan pengukuran umum produktivitas tenaga kerja kita memiliki unit-unit yang diperlukan, yakni: 
kuantitas hasil dan kuantitas penggunaan masukan tenaga kerja (Sinungan, 2003) Wuryanti (2010) mengemukakan bahwa teknik pengukuran produktivitas dapat dilakukan berdasarkan sumber datanya, yaitu: 1. Data faktual di lapangan dengan mengamati jumlah jam dan volume kerja langsung di lapangan. 2. Data historis dilakukan dengan mengkaji laporan harian/ mingguan/ bulanan.

\section{Pengertian Tenaga Kerja}

Menurut UU Pokok Ketenagakerjaan No. 14 Tahun 1969, tenaga kerja adalah setiap orang yang mampu melakukan pekerjaan baik di dalam maupun di luar hubungan kerja guna menghasilkan barang atau jasa untuk memenuhi kebutuhan masyarakat. Dalam hubungan ini maka pembinaan tenaga kerja merupakan peningkatan kemampuan efektivitas tenaga kerja untuk melakukan pekerjaan. Menurut UU No. 13 Tahun 2003 tentang Ketenagakerjaan, pengertian tenaga kerja adalah setiap orang yang mampu melakukan pekerjaan guna menghasilkan barang dan atau jasa baik untuk memenuhi kebutuhan sendiri maupun untuk masyarakat. Menurut Alam. S tenaga kerja adalah penduduk yang berusia 15 tahun keatas untuk negara-negara berkembang seperti Indonesia. Sedangkan di negara-negara maju, tenaga kerja adalah penduduk yang berumur antara 15 hingga 64 tahun. Dari beberapa pengertian diatas dapat disimpulkan bahwa tenaga kerja merupakan orang/manusia yang sedang mencari kerja atau yang sudah mendapat pekerjaan dan mampu melaksanakan suatu pekerjaan sehingga dari pekerjaan tersbut mendapatkan hasil berupa barang atau uang. Tenaga kerja merupakan faktor produksi yang sangat penting bagi setiap negara, di samping faktor alam dan modal. Tenaga kerja, modal, dan sumber daya alam merupakan faktor produksi yang berperan penting dalam meningkatkan jumlah produksi sekaligus mendorong peningkatan pendapatan negara.

\section{Metodologi}

Penelitian ini diselesaikan dengan metode analisis regresi berganda yang dimulai dengan perancangan kuesioner. Setelah kuesioner dirancang diuji validitas dan realibilitas. Setelah kuesioner dinyatakan valid dan realibel maka dibagikan kepada responden yang sebagian besar adalah pekerja dan pemilik perusahaan batako yang tersebar di Kota Kupang. Setelah itu pengumpulan data meliputi pengumpulan kembali kuesioner dari lokasi penelitian. Selain penyebaran kueisoner juga dilakukan wawancara terkait analisis faktor-faktor eksternal yang mempengaruhi produktivitas tenaga kerja pada pekerjaan pembuatan batako di Kota Kupang Kupang Nusa Tenggara Timur. Setelah kuisioner disebar dan dikumpulkan maka selanjutnya menganalisis data-data, baik berupa kuisioner maupun hasil wawancara. Analisis data menggunakan bantuan software Statistical Product and Service Solutions (SPSS) dengan analisis regresi berganda. Dari hasil analisis akan diperoleh faktor-faktor yang mempengaruhi produktivitas pekerja batako, faktor mana yang paling berpengaruh dan yang paling dominan berpengaruh terhadap produktivitas pekerja batako di Kota Kupang.

\section{Analisis dan Pembahasan}

\section{Umur Responden}

Umur responden yang dimintai pengisian kuisioner sebagai berikut : $10-19$ Tahun : 5 Orang, 20-19 Tahun : 22 Orang, 30-39 tahun : 20 Orang, 40-49 Tahun : 5 Orang dan diatas 50 Tahun : 5 Orang. Dengan demikian jumlah keseluruhan responden yang mengisi kuesioner berjumlah : 57 Orang. Selengkapnya dapat dilihat pada grafik dibawah ini 


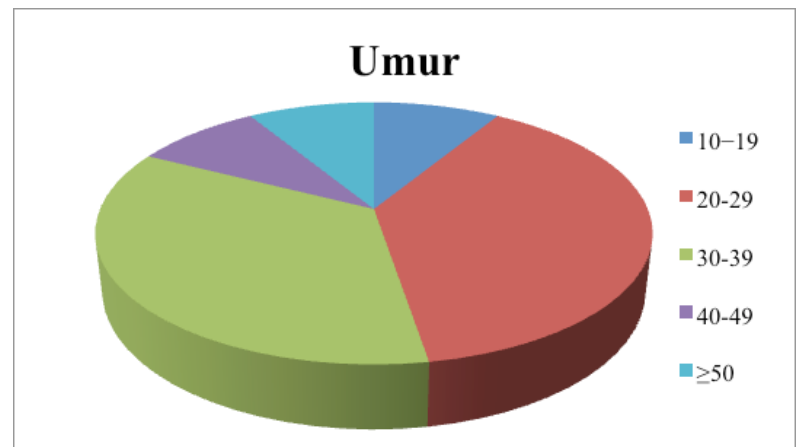

Gambar 1 Umur Responden

\section{Pendidikan}

Pendidikan responden yang dimintai pengisian kuisioner sebagai berikut : Tidak Sekolah : 6 Orang, Sekolah Dasar : 22 Orang, Sekolah Menengah Pertama : 16 Orang, Sekolah Menengah Atas : 8 Orang dan Sarjana : 5 Orang. Selanjutnya dapat dilihat dalam gambar 2.

\section{Pengalaman Kerja}

Pendidikan responden yang dimintai pengisian kuisioner sebagai berikut : 0-3 Bulan : 24 orang, $4-7$ Bulan : 18 orang, 8-10 Bulan : 6 Orang, 11-13 Bulan : 4 Orang dan diatas 14 Bulan : 5 orang. Lebih jelasnya dapat dilihat dalam gambar 3.

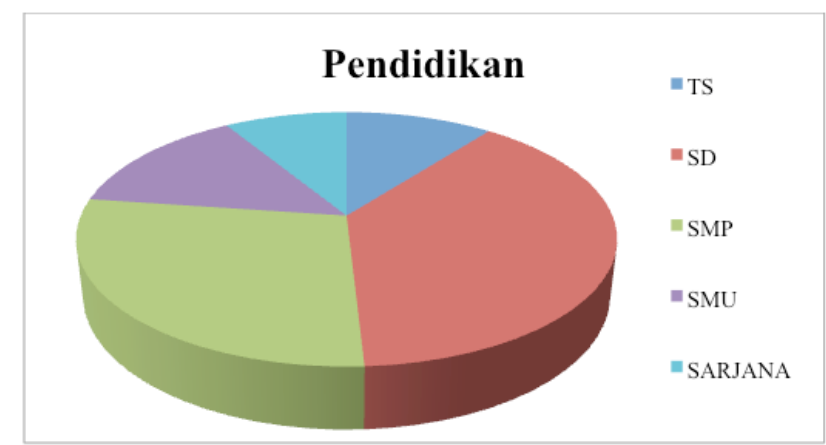

Gambar 2 Pendidikan Responden

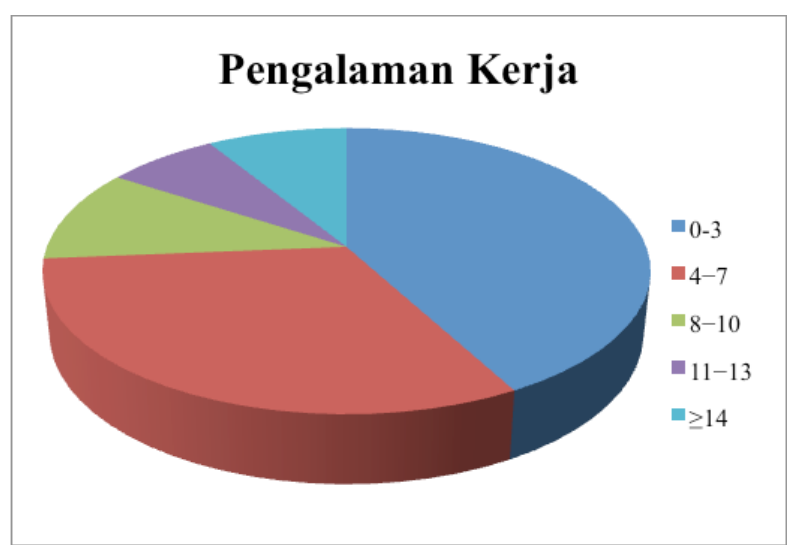

Gambar 3 Pengalaman Kerja Responden

\section{Faktor-Faktor Eksternal}

Faktor-faktor eksternal yang mempengaruhi pekerjaan batako di Kota Kupang antara lain : 
1. Faktor jarak bahan baku ke mesin pencetak.

2. Faktor kebersihan ditempat kerja

3. Faktor cuaca di tempat kerja

4. Faktor Upah Pekerja

5. Faktor Motivasi.

\section{Analisis Regresi Berganda}

\section{Perumusan Hipotesis}

Hipotesis dapat diartikan secara sederhana sebagai dugaan sementara. Jika dimaknai secara bebas, maka hipotesis berarti pendapat yang kebenarannya masih diragukan. Untuk bisa memastikan kebenaran dari pendapat tersebut, maka suatu hipotesis harus diuji atau dibuktikan kebenarannya. Perumusan hipotesis adalah kesimpulan yang ditarik sebagai jawaban sementara terhadap masalah penelitian. Tujuan perumusan hipotesis adalah sebagai langkah untuk memfokuskan masalah, mengidentifikasikan data - data yang relavan untuk dikumpulkan menunjukkan bentuk desain penelitian, termasuk teknik analisis yang akan digunakan.

H1 = Terdapat pengaruh Jarak Bahan Baku ke Mesin (X1) terhadap Produksi Perhari (Y)

$\mathrm{H} 2$ = Terdapat pengaruh Kebersihan di Tempat Kerja (X2) terhadap Produksi Perhari (Y)

H3 = Terdapat pengaruh Cuaca di Tempat Kerja (X3) terhadap Produksi Perhari (Y)

H4 = Terdapat pengaruh Upah Kerja (X4) terhadap Produksi Perhari (Y)

H5 = Terdapat pengaruh Motivasi (X5) terhadap Produksi Perhari (Y)

H6 = Terdapat pengaruh Jarak Bahan Baku ke Mesin (X1), Kebersihan di Tempat Kerja (X2), Cuaca di Tempat Kerja (X3), Upah Kerja (X4) dan Motivasi (X5) secara simultan terhadap Produksi Perhari (Y)

Tingkat kepercayaan 95\%, $\alpha=0,05$

\section{Dasar Pengambilan Keputusan}

a. Uji t

Uji t dikenal dengan uji parsial yaitu untuk menguji bagaimana pengaruh masing masing variabel bebasnya secara sendiri - sendiri terhadap variabel terikatnya. Dasar pengambilan keputusan dalam uji t sebagai berikut :

1. Jika nilai sig $<0,05$ atau $\mathrm{t}$ hitung $>\mathrm{t}$ tabel maka terdapat pengaruh variabel $\mathrm{X}$ (Jarak Bahan Baku ke Mesin, Kebersihan di Tempat Kerja, Cuaca di Tempat Kerja, Upah Kerja dan Motivasi) terhadap variabel Y (Produksi Perhari).

2. Jika nilai sig $>0,05$ atau $t$ hitung $<\mathrm{t}$ tabel maka tidak terdapat pengaruh variabel X (Jarak Bahan Baku ke Mesin, Kebersihan di Tempat Kerja, Cuaca di Tempat Kerja, Upah Kerja dan Motivasi) terhadap variabel Y (Produksi Perhari).

$$
\begin{array}{cl}
\mathrm{t} \text { tabel } & =\mathrm{t}(\alpha / 2 ; \mathrm{n}-\mathrm{k}-1) \\
& =\mathrm{t}(0,05 / 2 ; 57-5-1) \\
& =\mathrm{t}(0,025 ; 51) \\
\mathrm{t} \text { tabel } \quad & =2,00758 \\
\text { Dimana }: \alpha=\text { Tingkat kepercayaan } \\
\mathrm{N}= \\
\mathrm{k}=\text { Jumlah Sampel } \\
\quad \text { Jumlah variabel } \mathrm{x}
\end{array}
$$


b. Uji F

Uji $F$ merupakan uji yang mengukur ada atau tidaknya pengaruh simultan yang diberikan variabel $\mathrm{X}$ terhadap variabel $\mathrm{Y}$. Dasar pengambilan keputusan dalam uji $\mathrm{F}$ sebagai berikut :

1. Jika nilai sig $<0,05$ atau $F$ hitung $>F$ tabel maka terdapat pengaruh variabel $X$ (Jarak Bahan Baku ke Mesin, Kebersihan di Tempat Kerja, Cuaca di Tempat Kerja, Upah Kerja dan Motivasi) secara simultan terhadap variabel Y (Produksi Perhari).

2. Jika nilai sig $>0,05$ atau $\mathrm{F}$ hitung $<\mathrm{F}$ tabel maka tidak terdapat pengaruh variabel X (Jarak Bahan Baku ke Mesin, Kebersihan di Tempat Kerja, Cuaca di Tempat Kerja, Upah Kerja dan Motivasi) secara simultan terhadap variabel Y (Produksi Perhari).

$$
\begin{array}{ll}
\mathrm{F} \text { tabel } & =\mathrm{F}(\mathrm{k} ; \mathrm{n}-\mathrm{k}) \\
& =\mathrm{F}(5 ; 57-5) \\
& =\mathrm{F}(5 ; 52) \\
\text { F tabel } & =2,39
\end{array}
$$

Dimana : $\mathrm{k}=$ Jumlah variabel $\mathrm{X}$

$\mathrm{n}=$ Jumlah sampel

3. Pengujian hipotesis $\mathrm{H} 1, \mathrm{H} 2, \mathrm{H} 3, \mathrm{H} 4$ dan $\mathrm{H} 5$ dengan uji $\mathrm{t}$

Tabel 1 hasil uji analisis regresi linear berganda

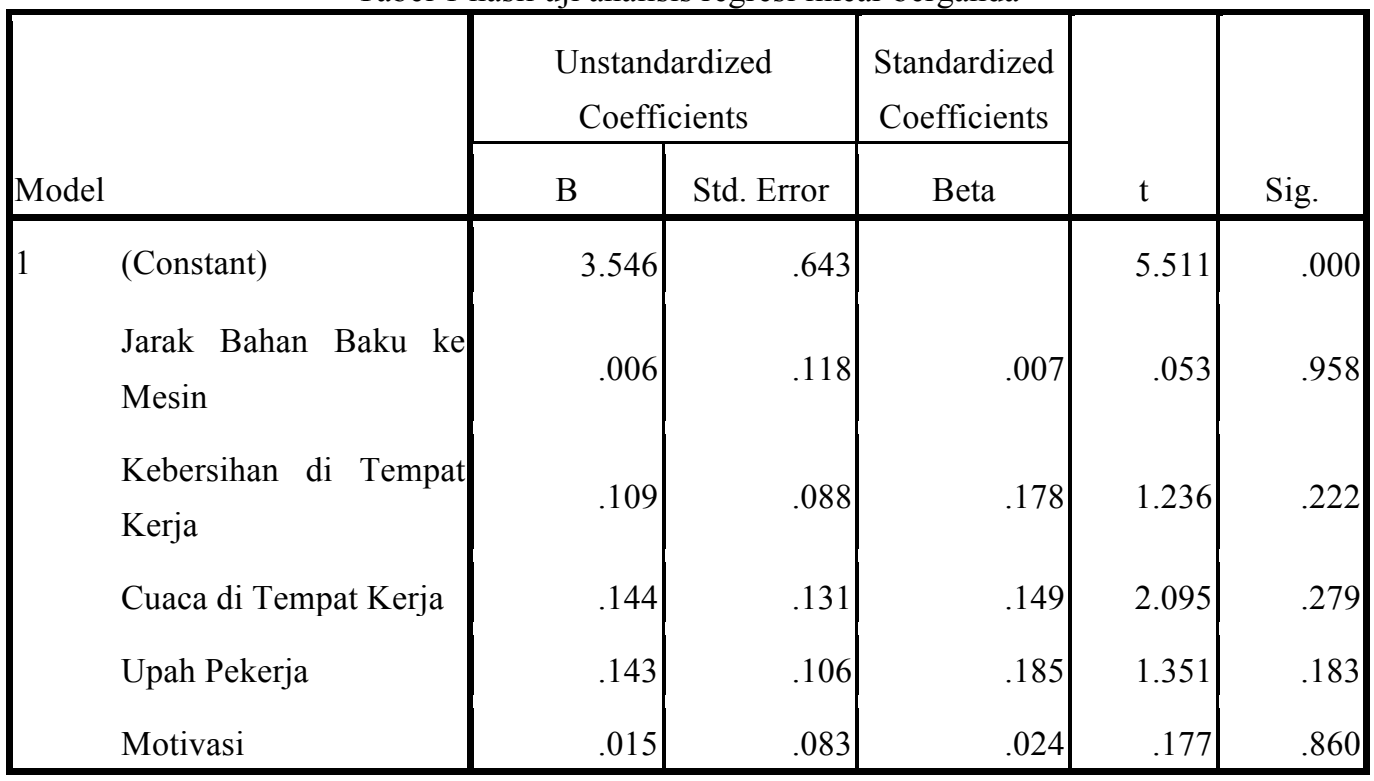

a. Dependent Variable: Produksi Perhari

Sumber : Hasil Analisa (Tahun 2019)

Dari tabel Coefficients dapat dilihat banyak hal terkait gambaran pengaruh setiap variabel independen terhadap variabel dependen secara satu persatu. Adapun penjelasan dari hasil output diatas sebagai berikut :

1. Pada kolom Unstandardized coefficients dapat diperoleh dua jenis informasi, yaitu nilai coefficients itu sendiri dan standar errornya. 
2. Pada kolom Standardized coefficients disajikan informasi mengenai nilai Beta dari setiap variabel independen yang ada. Namun dalam analisis regresi linear berganda informasi tersebut tidak dipakai. Nilai beta tersebut digunakan dalam Path analysis atau analisis jalur.

3. Pada kolom $\mathrm{t}$ diperoleh besarnya nilai $\mathrm{t}$ per variabel independen, nilai $\mathrm{t}$ digunakan sebagai tolak ukur terhadap pengaruh per variabel (parsial) dengan cara membandingkannya dengan nilai $t$ tabel.

4. Kolom sig memberikan informasi mengenai tingkat signifikansi setiap variabel independen untuk menentukan pengaruh tidaknya variable tersebut terhadap variabel dependen.

5. Pengujian Hipotesis Pertama (H1)

Diketahui nilai sig. untuk pengaruh X1 terhadap Y adalah sebesar 0,958 $>0,05$ dan nilai t hitung $0,053<\mathrm{t}$ tabel 2,00758, sehingga dapat disimpulkan bahwa H1 .ditolak yang berarti tidak terdapat pengaruh X1 terhadap Y.

6. Pengujian Hipotesis Kedua (H2)

Diketahui nilai sig. untuk pengaruh X2 terhadap Y adalah sebesar 0,222 $>0,05$ dan nilai t hitung 1,236 < t tabel 2,00758, sehingga dapat disimpulkan bahwa $\mathrm{H} 2$ ditolak yang berarti tidak terdapat pengaruh $\mathrm{X} 2$ terhadap $\mathrm{Y}$.

7. Pengujian Hipotesis Ketiga (H3)

Diketahui nilai sig. untuk pengaruh X3 terhadap Y adalah sebesar 0,279 $>0,05$ dan nilai t hitung 2,095 $>\mathrm{t}$ tabel 2,00758, sehingga dapat disimpulkan bahwa H3 diterima yang berarti terdapat pengaruh X3 terhadap Y.

8. Pengujian Hipotesis Keempat (H4)

Diketahui nilai sig. untuk pengaruh X4 terhadap Y adalah sebesar 0,183 $>0,05$ dan nilai t hitung 1,351< t tabel 2,00758, sehingga dapat disimpulkan bahwa H4 ditolak yang berarti tidak terdapat pengaruh $\mathrm{X} 4$ terhadap $\mathrm{Y}$.

9. Pengujian Hipotesis Kelima (H5)

Diketahui nilai sig. untuk pengaruh X5 terhadap Y adalah sebesar 0,860 $>0,05$ dan nilai t hitung $0,177<\mathrm{t}$ tabel 2,00758, sehingga dapat disimpulkan bahwa H5 ditolak yang berarti tidak terdapat pengaruh X5 terhadap Y.

\section{Pembahasan}

Berdasarkan hasil analisis yang telah dianalisa dapat diperjelas bahwa dari keseluruhan faktor yang sudah dianalisis yang memperngaruhi produktivitas tenaga kerja yakni :

a. Faktor cuaca. Faktor ini juga menjadi keluhan para pekerja, dimana pada bulan April hingga Oktober terjadi panas yang sangat menyengat dimana bisa mencapai 40 derajat celcius. Akibatnya produksi yang dihasilkan menurun bahkan sangat menurun.

b. Faktor jarak bahan baku ke mesin pencetak. Faktor jarak bahan baku ke mesin pencetak batako tidak mempengaruhi dikarenakan pada umumnya pekerja sudah memperhitungkan jarak ideal untuk mengangkut bahan baku ke mesin, proses pencumpuran dan pengeringan. Diusahakan tidak terjadi gesekan antara pekerja yang satu dengan yang lainnya sehingga produksi para pekerja sama sekali tidak terganggu.

c. Faktor kebersihan. Faktor Kebersihan ditempat kerja juga tidak mempengaruhi produktivitas tenaga kerja di mana pada umumnya tempat kerja (lokasi kerja) tetap terjaga kebersihannya.

d. Faktor Upah Pekerja. Faktor upah pekerja tidak mempengaruhi para pekerja dikarenakan pengupahan kepada tenaga kerja sudah dilakukan sejak tenaga kerja memasukan lamaran pertama kalinya dan diupah berdasarkan penghasilan perbatako. Sehingga pengupahan kepada tenaga kerja tidak mempengaruhi motivasi 
e. Faktor motivasi. Faktor motivasi juga tidak mempengaruhi produkksi pekerjaan batako. Hal ini dikarenakan para pekerja bekerja sesuai kemauan mereka yang artinya walaupun tanpa motivasi dan mereka membutuhkan penghasilna yang besar mereka dapat bekerja dengan lebih giat dan menghasilkan batako yang lebih banyak. Dengan demikian tidak ada pengaruh antara faktor motivasi dengan produksi tenaga kerja.

\section{Kesimpulan}

Berdasarkan analisa dan pembahasan yang telah dilakukan maka dapat disimpulkan antara lain :

- Dari kelima faktor eksternal yang dipakai untuk menentukan seberapa pengaruhnya terhadap produktivitas para pekerja batako di Kota Kupang maka yang berpengaruh adalah faktor Cuaca.

- Sedangkan keempat faktor lainnya yakni faktor jarak bahan baku ke mesin pencetak, faktor kebersihan, faktor upah dan faktor motivasi sama sekali tidak mempengaruhi produktivitas para pekerja batako

- Solusi: Berkaitan dengan cuaca yang panas disarankan agar kalau bisa manajer atau pemilik perusahaan membangun sebuah bangunan yang besar dan panjang sehingga para pekerja bekerja didalam bangunan dan bukan diluar bangunan.

\section{Daftar Pustaka}

Darmono. (2006). Teknologi pembuatan bahan bangunan berbahan pasir (Batako) hasil erupsi Merapi di Lereng Bagian Utara. Jurnal Inotek, 16(1)

Ervianto, W. I. (2005). Teori-Aplikasi Manajemen Proyek Konstruksi. Yogyakarta: Andi Offset

Harun, M. (2013). Analisa Produktivitas Tenega Kerja Pada Pekerjaan Konstruksi Gedung. Jurnal Ilmiah Mitsu, 1(2)

Hasibuan, M. (1996). Organisasi dan Motivasi Dasar Peningkatan Produktivitas. Jakarta: Bumi Aksara

Simanjuntak, M.R.A. dkk. (2012). Analisis Faktor-Faktor dan Variabel Produktivitas Pekerjaan Fasade Kaca Pada Bangunan Gedung Tinggi Perkantoran Di Kawasan Kuningan Jakarta Selatan. Jurnal Ilmiah Media Engineering, 2(1)

Soeharto, I. (2001). Manajemen Proyek: Dari Konseptual sampai Operasional. Jakarta: Erlangga

Sutikno. (2000). Faktor - faktor Yang BerpengaruhTerhadap Produktivitas Pemasangan Dinding Batu Bata Di Proyek Perumahan Vila Bukit Mas

UU Pokok Ketenagakerjaan No. 14 Tahun 1969 tentang Ketentuan-Ketentuan Pokok Mengenai Tenaga Kerja

UU No. 13 Tahun 2003 tentang Ketenagakerjaan

Wuryanti, W. (2010). Standarisasi Pedoman Pengukuran Produktivitas Tenaga Kerja untuk Pekerjaan Konstruksi Bangun Gedung. Prosiding PPI Standardisasi Banjarmasin 